\title{
THE APPROACH OF SOCIAL ANTHROPOLOGY AND HISTORICAL SOCIOLOGY TO THE INDONESIAN CONTEMPORARY STUDY ON MUSLIM'S DEMOCRACY
}

\author{
Yasmin Kusumawati \\ Alumni of the Atma Jaya Catholic University of Indonesia in Jakarta \\ yasminkusuma04@gmail.com
}

Title

: Civil Islam: Muslims and Democratization in Indonesia

$\begin{array}{ll}\text { Author } & : \text { Robert W. Hefner } \\ \text { Publisher } & : \text { Princeton University Press } \\ \text { Year } & : 2000 \\ \text { Page } & : 286 \\ \text { ISBN } & : 978-0691050478\end{array}$

\begin{abstract}
:
In Civil Islam: Muslims and Democratization in Indonesia, Professor Robert W. Hefner challenges a notion that downgrades the peripheral status of Islam in Indonesian studies ${ }^{1}$ by concerning himself with answering a question: Did Indonesian Muslims resist democracy? ${ }^{2}$ The author answers this from theoretical and empirical perspective. ${ }^{3}$
\end{abstract}

\section{Discussion}

Theoretically, he occupies himself with social anthropology to seek social groups' behaviours, and historical sociology to uncover social proportions: moments and events. ${ }^{4}$ So Hefner looks supposedly not only the present time (reform period), but also all the way back to the pre-reform era: the Old Order presided by Soekarno (1945-1965), and the old one by President Soeharto (1965-1998). Empirically, Hefner conducted his field work in three phases: 1970s, 1985, ${ }^{5}$ and each summer during 1990s (till 1998). ${ }^{6}$ He lived in

${ }^{1}$ Robert W. Hefner, Civil Islam: Muslims and Democratization in Indonesia, (Princeton and Oxford: Princeton University Press, 2000), p. ix. I am fully grateful to Usep Abdul Matin, S.Ag., M.A., M.A., Ph.D. for guiding me in reviewing this book.

${ }^{2}$ Ibid., p. vii

${ }^{3}$ Ibid.

${ }^{4}$ Ibid., pp. xix, 157.

${ }^{5}$ Ibid., p. xiii

${ }^{6}$ Ibid., p. xviii 
Pauruan in East Java, where the most powerful membership prevailed, ${ }^{7}$ but he interviewed more than four hundred people elsewhere in Indonesia. ${ }^{8}$

Civil Islam consists of eight chapters, in which Hefner argues that Indonesian contemporary Muslims insist a greater political participation that we must see in a hybridic way, in which we should arrive at this input's changing cultural contexts (historical background of culture, social pluralism, and state violence of the pre-reform age). ${ }^{9}$ To acquire this multiple insight, Hefner sees Muslims' involvement in democracy from everything in a crosscultural entity, such as nationalism, religious conversion, capitalism, and democratic movement. ${ }^{10}$

I observe Hefner's multiple insights from his explanation about mass organizations, like the Association of Indonesian Muslim Intellectuals (ICMI) and Nahdlatul Ulama (NU). In regard to ICMI, Hefner complicates this organization's particles ranging from its membership, its ideology, its role, to its idol, each of which is liable to diverge. In terms of membership, Hefner differentiates it into two: Muslim intellectuals and political-change activists. However, each of these two groups continues to differing into other components due to their different ideologies: those who support President Soeharto, and those who oppose him. This divergence, nevertheless, is not exclusive because many of ICMI's members combine their role as both scholars and activists. There are, nonetheless, few independent intellectuals of all ICMI's members; yet, this minority has the greatest influence to both ICMI and Muslim public.

Hefner refers to (late) Nurcholish Madjid (Cak Nur) to describe him as the idol of ICMI though Hefner provides with an account that says that Cak Nur is less influential to ICMI. As a matter of fact, Hefner comes with strong evidences saying that Cak Nur had been promoting Islamic vision of civil democracy since 1970 as he drafted ICMI's targets and organization structure in 1990. In the meanwhile, public, in particular middle-class Muslims, considered Cak Nur to be a spiritual leader of ICMI. In fact, Cak Nur rejected politicization of Islam, while he advocated the influence of Islam to public life and politics. ${ }^{11}$

Hefner, then, puts Cak Nur in opposition to Muslim conservatives (, like Dewan Dakwah Islamiyah Indonesia) who, in 1991 and 1992, used this organization to go against Christians and nationalists; in contrast, Cak Nur continued promoting religious tolerance. In 1993 and 1994, Cak Nur kept advocating free speech and public criticism for democracy and society by

\footnotetext{
${ }^{7}$ Ibid., p. xiii

${ }^{8}$ Ibid., p. xxi

${ }^{9}$ Ibid., pp. vii, xvii.

${ }^{10}$ Ibid., p. xvii

${ }^{11}$ Ibid., p.143.
} 
encouraging a "principled political opposition", including multi party in addition to consultation and consensus. Moreover, Cak Nur did not stop his tolerance campaign in 1996 and 1997, when ethno religious violence occurred. In fact, he went public in opposition to Soeharto in his last month of presidency. $^{12}$

Hefner's idea of the most influential few (Cak Nur) inspires me to wonder whether this category is unidirectional ethnocentrism since Hefner's elucidation of Cak Nur reminds me of Clifford Gertz's influential Westerneducated prijaji. Cak Nur is also a well-educated man who graduated from Chicago University in the US. However, I might consider well Hefner' finding of popular-sovereignty-principle-based democracy that the majority of ICMI adhered. Hefner also breaks profoundly this most influential few into two other sub few: Jalaluddin Rakhmat and Ismail Suny who were pro God-based power, an idea originated in Mohammad Natsir (leader of Masyumi) in the 1950, and Amin Rais, including Ali Yafi , who assume presidency reservation for a Muslim. It is evidenced by the fact that Rais promoted distinction between Muslim and protected minority. ${ }^{13}$

Like his explanation about ICMI, which is full of complex and shifting connections between this organization and the state, Hefner does the same approach to his clarification of NU. Hefner examines the critics who argue that NU's complex and shifting relations to the government of the Old Order and the new one were a simply opportunist. Hefner opposes to this idea by saying that these relations of NU to the state was its "expression from within": It was an NU's political behaviour patterned before independence (1945).

Hefner clarifies that NU had unusually dual leadership since it was founded in 1926: the executive body (Tanfidziyah) that included pragmatic politicians based in Jakarta, and the council of religious scholars (Syuriyah) that encompassed top Muslim learned men ('ulama') across Indonesia. In 1940, NU had an underground meeting with Soekarno to vote him as the future president of Indonesia, though his rival (Hatta) was more pious than him. As a result, NU maintained its ministry [of state] in 1945 [and in 1946]. In 1945, NU joined modernist Masyumi to support Pan Islamic political federation. In consequence, NU had been sustaining its employment monopoly in the ministry of religion since 1950s. In 1952, NU withdrew from this federation because most of its members were modernist (Masyumi), most of which were well-educated. ${ }^{14}$

This circumstance led NU to shift its management from daily affairs by recruiting well-educated secular politicians; in the meanwhile, Syuriah

\footnotetext{
${ }^{12}$ Ibid., p. 144.

${ }^{13}$ Ibid.

${ }^{14}$ Ibid., p. 87.
} 
granted this as long as they shielded the interest of Muslims and the role of NU. This sloppy behaviour penetrated evidently to the decentralized structure of NU's traditional Qur'anic boarding schools (pesantren-s) headed by charismatic religious leaders (kiyai-s). ${ }^{15}$

Hefner adds that NU continued shifting its compromises from 1957 to 1960, when it was loyal to President Soekarno and his armed forces in countering the rebels of modernist Islam and sentiment of anti Java. Nevertheless, though NU was the most important player in Soekarno's government of national unity (Nationalism, Religion, and Communism/NASAKOM) from 1959 to 1965 , NU turned to be in favour of an Islamic state, and rejected Soekarno's call for returning to Constitution 1945 and for establishing Guided Democracy. In turn, NU was also willing to make special consideration to Soekarno's government. ${ }^{16}$

Hefner clarifies that these compromises of NU indicate that "complex balancing of multiple interests" guide NU's "logic of concrete". The abstract principles or ideological purity did not direct this organization. Hefner strengthens his argument by referring to Samson's finding of NU's "contextual logic"; it defended traditionalist Islam and maintains the interests of religion and individual as the result of NU's less-"goal-centered" political party. ${ }^{17}$ Hefner elucidates that these interests refer to NU's persuasive "mix nationalism, Javanese ethnic pride, and multi interest pragmatism" linked not to ideology, but to NU's 'ulama' who took a lead of the core of this party. ${ }^{18}$

Hefner, then, compare this contextual concrete of NU, which was far from its ideological decontamination to a larger society in the West, where Protestants and Catholics agreed to stop killing each other "not because of some sudden theological enlightenment." It was because of decades of bloodshed in the Sixteenth and Seventeenth century that led the people to realize that "post-Reformation wars of religious purification were unwinnable and a greater evil than religious diversity". ${ }^{19}$ Therefore, Hefner sees that NU's flexible negotiations might have an enduring impact on politics in the future as this organization has to raise itself beyond its "immediate self-interest and mere political expedience." 20

This multiple approach of Hefner makes me realize that historical sociology and social anthropology have led Hefner to focus on the contextual elements of his informants. My question would be: Can I dig the information of my future respondents not only from their contextual realms, but also from

${ }^{15}$ Ibid., p. 88 .

${ }^{16}$ Ibid., p. 86.

${ }^{17}$ Ibid., p. 87.

${ }^{18}$ Ibid.

${ }^{19}$ Ibid., p. 88.

${ }^{20} \mathrm{Ibid}$. 
The Approach of Social Anthropology and Historical Sociology to the Indonesian

Contemporary Study on Muslim's Democracy

their textual ones by using linguistic anthropology? I ask this because, in daily life as I befriended with my NU's colleagues in Indonesia, including my late grandpa who was devoted to NU's rituals, they usually connect their problems to solve to the logic of Shafi'ite jurisprudence (fiqh). By so doing, I might transform my Islamic studies research from sacred texts to variety of practices. 
Yasmin Kusumawati

150 | INDO-ISLAMIKA, Volume 9 No.1 Januari-Juni 2019/1440 